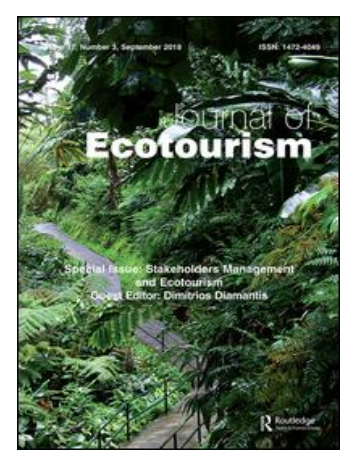

Journal of Ecotourism

\title{
Promoting sustainable tourism in rural and natural areas through small business innovation: the case of Atenor village (Northeast, Portugal)
}

\section{A. M. Antão-Geraldes \& V. A. Sheppard}

To cite this article: A. M. Antão-Geraldes \& V. A. Sheppard (2019): Promoting sustainable tourism in rural and natural areas through small business innovation: the case of Atenor village (Northeast, Portugal), Journal of Ecotourism, DOI: 10.1080/14724049.2019.1607864

To link to this article: https://doi.org/10.1080/14724049.2019.1607864

曲 Published online: 25 Apr 2019.

Submit your article to this journal $\widetilde{ }$

山 Article views: 3

View Crossmark data $\complement$ 


\title{
Promoting sustainable tourism in rural and natural areas through small business innovation: the case of Atenor village (Northeast, Portugal)
}

\author{
A. M. Antão-Geraldes (1D) ${ }^{a}$ and V. A. Sheppard (1D ${ }^{b}$

 \\ Hospitality, Universidade Europeia, Lisbon, Portugal
}

ARTICLE HISTORY Accepted 3 April 2019

\section{Introduction: regional \& local context}

Douro International is a cross-border mountainous region located between northeast Portugal and northwest Spain (see Figure 1). The Portuguese side is one of the most remote regions of the country. It has a diversity of natural, semi-natural habitats, and humanized landscapes, which are important repositories of biodiversity and cultural heritage. Indeed, this region has a high floristic importance (Carvalho \& Frazão-Moreira, 2011) and is one of the most important areas for fauna within Portuguese, Iberian and European contexts.

The region's wild vertebrate fauna comprises 238 species, including 28 mammals, 168 birds, 17 reptiles, 11 amphibians and 14 fish. Concerning birds, this region is one of the most important European nesting habitat for rupicolous birds, such as the following endangered species: Griffon vulture (Gyps fulvus), Egyptian vulture (Neophron percnopterus), Golden eagle (Aquila chrysaetos), Bonelli's eagle (Hieraaetus fasciatus) and Black stork (Ciconia nigra) (Monteiro, 2011; Van Beest, Van Den Bremer, De Boer, Heitkönig, \& Monteiro, 2008). Agriculture (traditional production of wine, olives, almonds, wheat and rye) and extensive livestock, mainly with regional breeds well adapted to local ecological conditions (e.g. sheep breed 'churra galega mirandesa', goat breed 'Serrana ecotype transmontano' and to a lesser extent, the cow breed 'mirandesa') play a relevant role in economic-productive terms, for their organic-like quality, contributing to a sustainable use of natural resources and maintenance of rural landscaping (Rodrigues, Cadavez, \& Teixeira, 2006; Sousa et al., 2018). The highly threatened donkey breed, Asinina de Miranda, is still part of the agricultural heritage. Although, it is currently less used in transport and traction. Today, this breed is increasingly used as a companion animal and in ecotourism activities (Quaresma, Martins, Rodrigues, Colaço, \& Payan-Carreira, 2014).

Overall, the region has an extremely rich, historical, cultural and architectural heritage (Fernandes, 2015). However, similar to other rural inland and border areas, this region has developmental and economical constraints, which were caused by and have led to the ongoing loss of population for the past several decades. According to INE (2012), currently there are about 13,500 inhabitants in this area, distributed amongst 46 villages (many of them with less than 100 inhabitants). From 1981 to 2011 the population decreased by $40 \%$.

CONTACT V. A. Sheppard vsheppard7@gmail.com

(C) 2019 Informa UK Limited, trading as Taylor \& Francis Group 




Figure 1. Location of Douro International and Atenor village. (Source: Google Maps).

The International Douro Natural Park (see PNDI http://www2.icnf.pt/portal/turnatur/ visit-ap/pn/pndi), created in 1998, is located within this region, covering a narrow area of approximately $860 \mathrm{~km}^{2}$. It encompasses the Douro's and Águeda rivers fluvial canyons (see Figures 1 and 2). In 2015, this geographic area was included in a broader protected

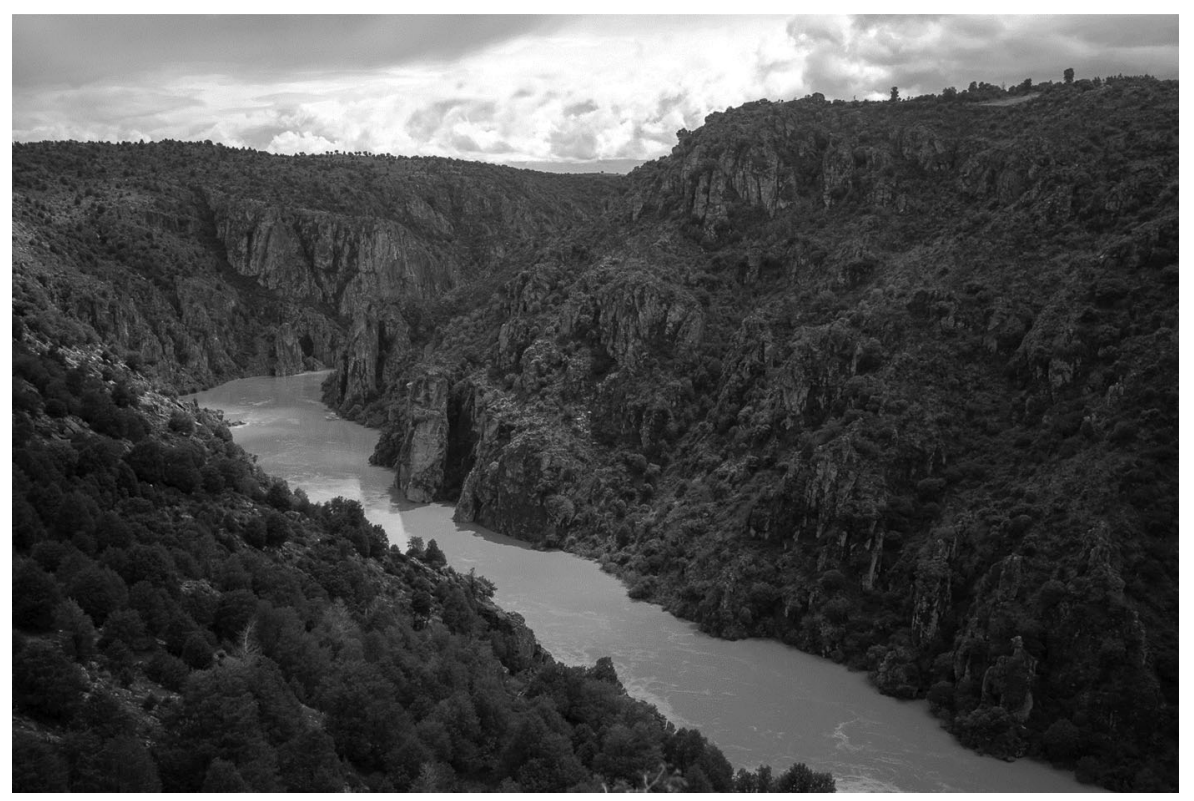

Figure 2. The International Douro Natural Park: River Douro canyon. (Source: José Jambas). 
area: The Meseta Iberica Transborder Biosphere Reserve MaB UNESCO (see http://www. biosfera-mesetaiberica.com/es and http://www.biosfera-mesetaiberica.com/pt-pt).

Consequently, the region offers remarkable potential in terms of natural and cultural resources which, if properly utilized and managed from a conservation perspective, could contribute to its revitalization. In this sense, sustainable tourism and ecotourism activities, implemented from a small business perspective, could promote sustainable development and revitalization of this region. The objective of this field note is to disclose two unconventional and innovative small businesses that are operating in Atenor, a small village, with less than 100 inhabitants, located in the vicinity of the PNDI.

\section{Overview of business owners \& their business philosophy}

Bárbara Fráguas and José Jambas have been living in Douro International region since 1995. In 2008 they moved to Atenor, where they currently live with their two young children. Atenor $\left(41^{\circ} 26^{\prime} 04.85 \mathrm{~N} ; 6^{\circ} 29^{\prime} 05.77 \mathrm{~W}\right)$ is a small village with approximately 80 inhabitants, of which only seven are less than 15 years old and most of whom are over the age of 60 (B. Fráguas \& J. Jambas, personal communication, July 2018). Bárbara and José have past work experience as environmental consultants in several projects and studies concerning fauna monitoring and conservation. These activities enabled them to acquire vast knowledge of the region, including the local species and cultural heritage. Additionally, they have been involved with other dynamic young people coming mainly from the developed littoral part of Portugal, to create two local, developmental non-governmental organizations (NGOs): ALDEIA (see http://www.aldeia.org/) and AEPGA (Association for conservation of donkey breed Asinina de Miranda) (see https://www.aepga.pt/). This latter association is located in Atenor.

Both Bárbara and José believe that it is possible to develop, in articulation with the local inhabitants, parish councils, and other governmental entities, sustainable and complementary small business opportunities that enable the creation and or re-creation of traditionaltype jobs. They also contend that this, in turn, will lead to the enhancement of the natural and cultural heritage of the place and the region in which they live, potentially reducing the chronic developmental and economical constraints that are the result of population degrowth. In the following sections, we provide details about the two businesses created and operated by Bárbara and José that demonstrate the possibilities for small business innovation, enhanced through the creation of natural, local products and small-scale tourism activities.

\subsection{Business \#1: landscapes, green gardens, sheep, donkeys and birds: promoting sustainable tourism activities}

In 2006, Bárbara and José founded the Oriolus, Ambiente e Ecoturismo, Lda (after passerine genus Oriolus), whose main mission is to promote the knowledge of the natural and cultural heritage of the region through sustainable tourism activities. Under this scope they recovered the Casa da Ti Cura (http://www.casadaticura.com/), using raw materials from the region. The Casa consists of a set of three rural tourism lodgings. The tourists, coming mostly from Spain, England, France and the Netherlands, and to a lesser extent Portugal, Russia and Israel, have a chance to do several activities while lodging at the 
Casa. These activities range from self-guided nature walks and regional visits to the surroundings, to guided activities. Such activities include autumnal observation of the roar of the red deer (Cervus elaphus), searching for signs of the Iberian wolf (Canis lupus signatus), nature photographic safaris, and bird watching. Guests also have the chance to interact with Atenor inhabitants when they choose one or more of these activities. For example, guests may choose an interpretive visit to the village vegetable gardens, an opportunity to work as a shepherd for a day, or to take a guided donkey riding tour with AEPGA donkeys. In alignment with Bárbara and José's concern for the welfare of their animals, the donkeys live freely in an extensive open area surrounded by meadows and scrubland, with access to shelters, feeding places, and veterinary care. While the donkeys are used for transportation of guests, the donkey tours are focused mainly on transporting children and some supporting material (food, photographic material, etc.).

Recently, in order not only to differentiate the touristic offering, but also to achieve a greater contribution to wildlife conservation, four permanent wildlife photography hides were built (see Figure 3). They are located in distinct habitats. Photographers, professionals or not, and guests in general can enjoy memorable experiences and become acquainted with local wildlife, without disturbing nesting and feeding areas. Local schools may also have access to the hides for free. One of the hides is located nearby to a scavenger feeding station, on private land in Atenor. This hide allows the observation of the threatened vultures and other birds of prey (see Figure 4). The construction of the hides were authorized by Institute for Conservation of Nature and Forestry (ICNF). As part of this agreement, a portion of Oriolus's income is used to finance, as required, the certified carcasses for the scavenger feeding stations, contributing to the conservation of these birds. In this region, because of the decline of large mammals populations, dead cattle become a very important source of food for these birds. However, as a consequence of the Bovine Spongiform Encephalopathy crisis- an animal disease with serious human health implications, that could be spread through the presence of dead cattle, the Portuguese authorities required livestock breeders to remove dead animals from the field. Even

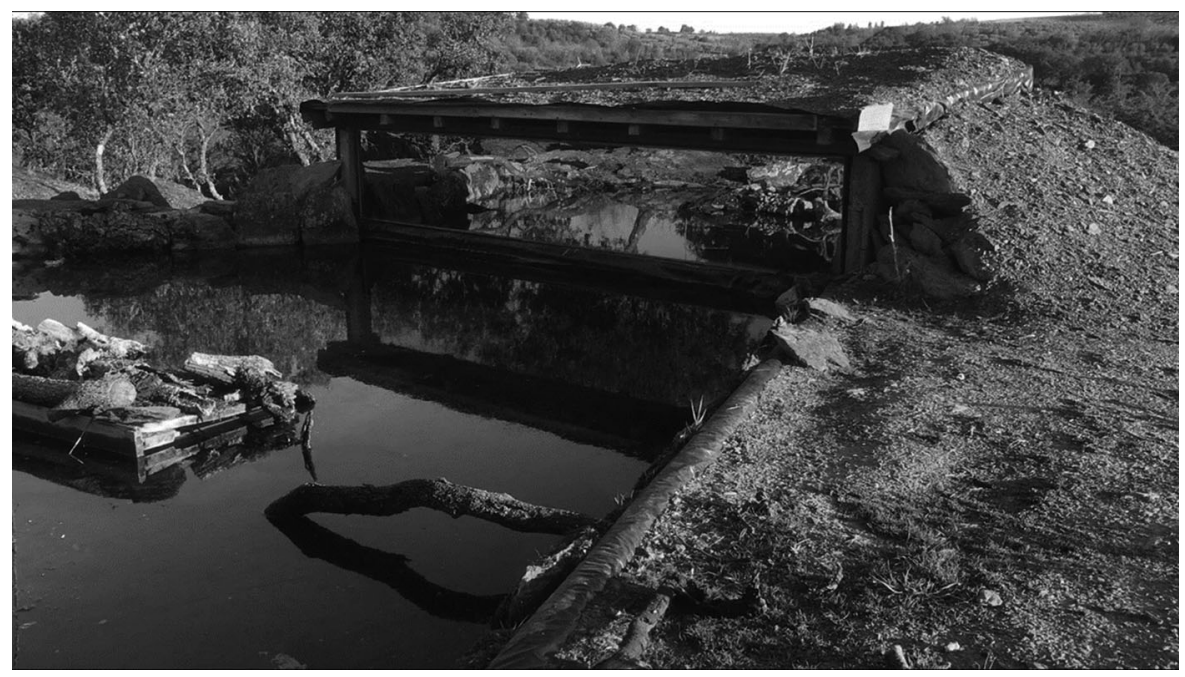

Figure 3. Wildlife photography hide (Source: José Jambas). 


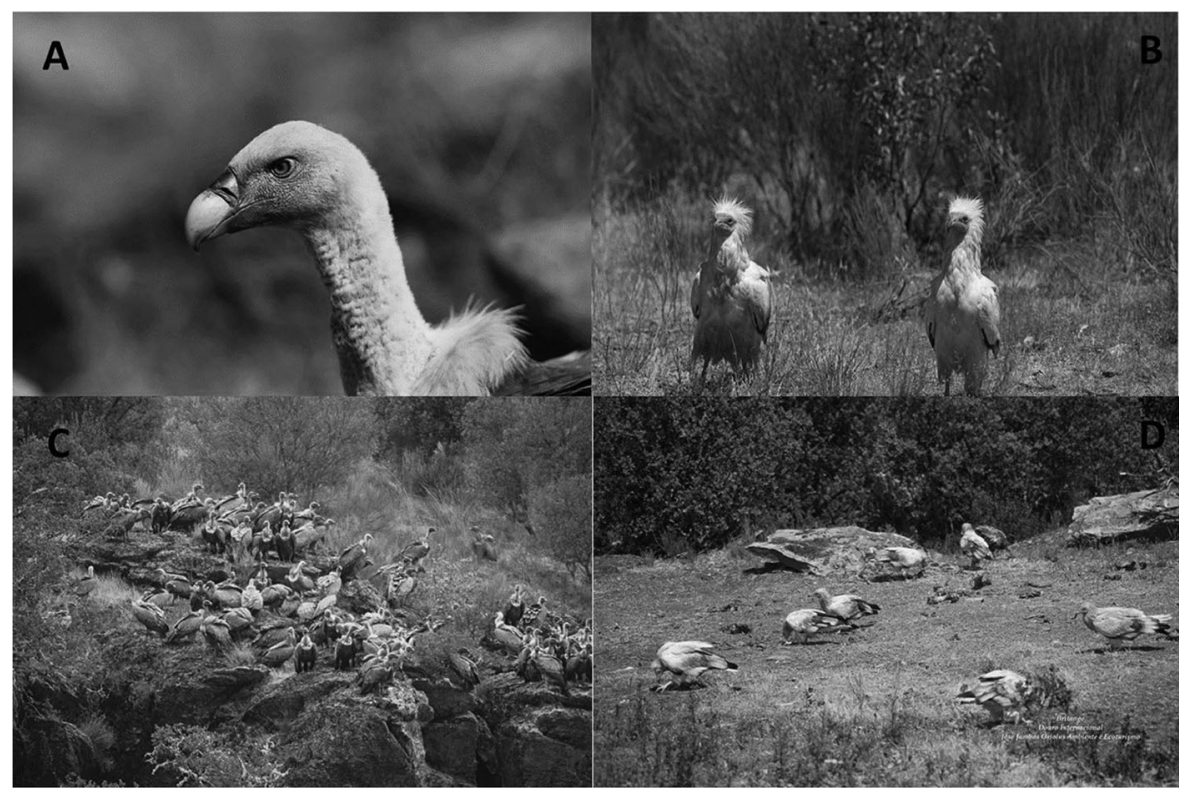

Figure 4. A: Observation of Griffon vulture (Gyps fulvus) and B: Egyptian vulture (Neophron percnopterus). Photos taken from a wildlife photography hide located nearby a scavenger feeding (C and D) (Source: José Jambas).

now, more than 20 years after the crisis, the removal of dead cattle is still mandatory, except for a few scavenger feeding stations that may be supplied with livestock carcasses under very restrictive licensing conditions (Arrondo et al., 2018).

\subsection{Business \#2: donkeys \& sheep: promoting local culture and traditional crafts through the use of re-discovered raw materials}

Bárbara and José are also donkey breeders. In a field, with about three hectares, located adjacent to Casa da ti Cura, they have 13 donkeys of the authochtonous breed, Asinina de Miranda (11 females and 2 males) (see Figure 5). The field provides adequate and

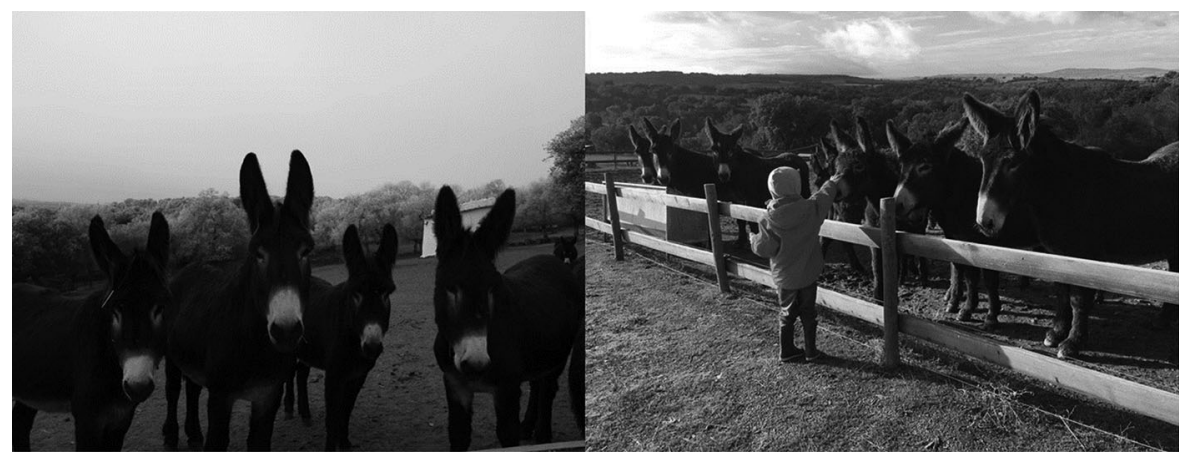

Figure 5. Miranda breed donkeys. Tourists and visitors can interact with the donkeys (Source: Bárbara Fráguas). 
suitable pasture for grazing and exercise. Donkeys also have access to the stable 24 hours a day and, as required, necessary veterinary care. Their donkey breeding activities have led to their involvement in the creation of another business known as Tomelo, Eco Desenvolvimento, Lda (see https://www.tomelo.pt/en/). The name Tomelo is the designation for lavender (Lavandula stoechas) in the Mirandês language. Mirandês is the second official language of Portugal and is only spoken in this region. Tomelo's mission is to promote local sustainable development in an ecologically conscientious manner, that includes a focus on community (human and animal) well-being. The main product produced by the company is a line of cosmetics made with an almost forgotten raw material ... the milk of this specific donkey breed.

The company's products are sold online and in a shop located in Porto, Portugal (see Figure 6). These products are also resold in several shops located in Portugal, Spain, France, Netherlands and Germany. The Porto shop is not only dedicated to the sale of these cosmetics, but also the sale and promotion of other regional products and crafts produced in Douro International region. More recently, an exfoliating donkey milk soap was created as a result of the partnership between Tomelo and the Lhana Project (see http:// www.cienciaviva.pt/lpp/Img/lhana/PROJECTO_LHANA_little.pdf). Lhana wool comes from the autochthonous sheep breed of Mirandês. The soap, coated with the wool, acts as a natural exfoliant. As such this product combines traditional raw materials from both the milk of donkeys and the wool of the sheep to create a unique, sustainable product (see Figure 6).

\section{Key business-related achievements}

Both businesses, highlighted in the previous paragraphs, are complementary: the first promotes sustainable development by allowing tourists and visitors to get acquainted 'in loco'

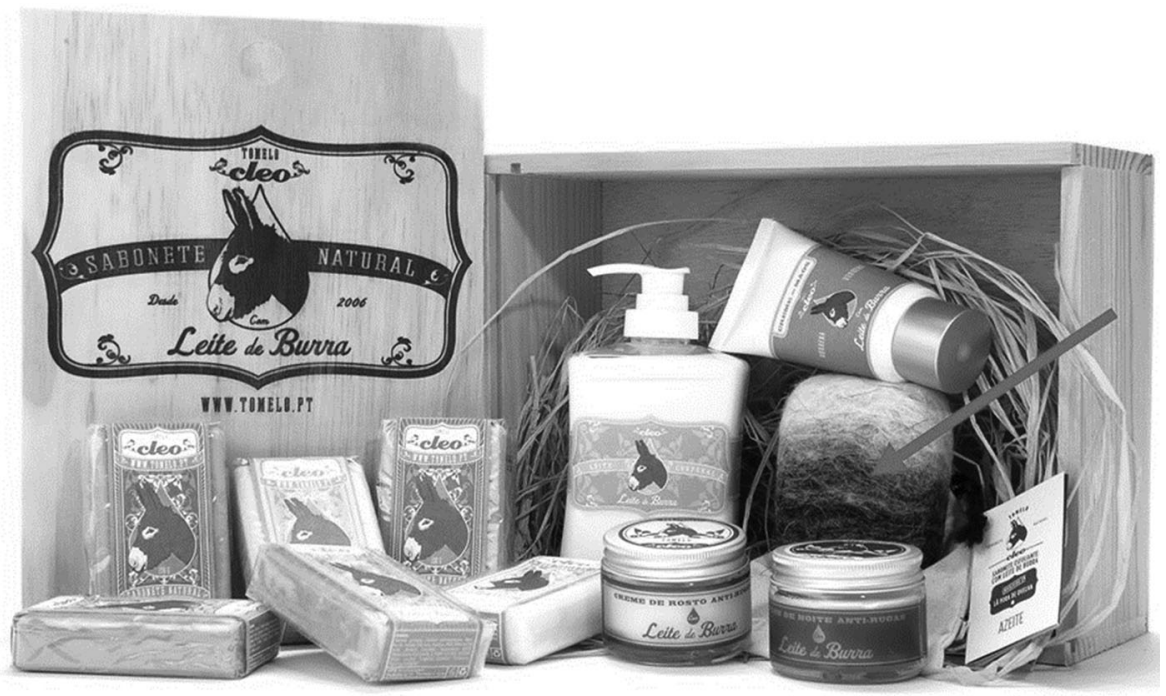

Figure 6. Cosmetic line made of donkey milk and donkey milk soap coated with wool (as indicated with an arrow) (Source: TOMELO). 
with the natural and cultural values of the region; the second promotes the indirect knowledge of the region through the promotion of regional and handicraft products made of local resources (human and animal) and local raw materials (i.e. linen, wool, clay, wicker, and donkey milk), many of which had fallen into disuse over time. Despite the different strategies, both projects share the same final objectives and commitments: environmental sustainability, nature conservation, fair trade, animal welfare and the enhancement of the direct and indirect value for the local community.

Overall, employment opportunities and the reinvestment of revenues into the region have been the main achievements of these endeavors. Not only have Bárbara and José created their own jobs, but also employment opportunities for local inhabitants. For example, cosmetic labels are printed in a typography (a local shop) located in a nearby village, and the Porto store has added three new employment positions. As it relates to the revenues, these are fully reinvested within the region. For instance, part of the company's income is used to finance conservation (i.e. conservation of endangered species of vultures and other birds of prey and of the authochnous donkey breed), research activities (i.e. evaluation of the efficiency of the scavenger feeding stations, bird ringing and research concerning ecology and biology of birds), educational activities (i.e. bird ringing and activities in photography hides for children and young people from local schools) and cultural projects (i.e. contribution in founding and organizing the local event 'Ronda das Adegas'). The Ronda das Adegas is an annual event promoted by the local municipality. It promotes local wines, gastronomy, and the re-creation of traditional crafts (Figure 7). This event is attended by hundreds of people from across the region, and also from other parts of Portugal, Spain and beyond (see http://www.rotaterrafria.com).



Figure 7. 'Ronda das Adegas' (Source: José Jambas). 


\section{The future: opportunities for sustainable tourism business innovation}

The business activities highlighted in this paper provide examples of innovative and sustainable business operations and practices that are occurring in a rural and natural setting. Such businesses offer hope for future generations who seek sustainable livelihoods and lives outside major cities. Indeed, it is crucial to the sustainability of rural and natural areas that tourism development opportunities be guided by small-scale tourism development strategies, such as these, as opposed to focusing on growth strategies. The principles for small-scale tourism development can be found within the principles of sustainability; however, this can only occur through the cooperation of and between stakeholders, including businesses, public administrators (e.g. park management sector, municipalities, parish councils), the community, visitors and academia. Yet, it is the diversity of these stakeholders, each with their own agendas, that is often responsible for the gap between policy endorsement and policy implementation (Pigram, 1990). Indeed, current management approaches that have sought to address the economic, socio-cultural, and environmental challenges of small villages and towns are not usually harmonized nor linked. Consequently, small sustainable business, including those focused on tourism activities, are still scarce in rural and natural areas and they are often poorly funded by regional and national development trusts.

\section{Conclusion}

Despite these challenges, tourism-focused activities in rural and natural areas of low population density are rapidly increasing (Kastenholz et al., 2014). Indeed, rural tourism and ecotourism can be a catalyst for the regeneration and economic development of rural areas, where the traditional economic activities are declining. The potential increase of the attractiveness of these areas enhances the local community's pride and self-esteem, as well their awareness for the value of local natural and cultural heritage. Therefore, the positive effects will tend to be more intense if tourism is developed using endogenous resources. This includes a focus on the natural and cultural heritage of a region, which provides opportunities for visitors to interact with the local community. The jobs that are created as part of this interaction, in turn, have the potential to slow down and perhaps reverse the population decline in rural areas.

Overall, the positive effects of the development of tourism in rural destinations will only occur in the medium and long term unless if it aims to simultaneously meet the needs of all stakeholders involved in the process. Underlying these aims are the conservation of the resources that serve as the basis for the development of tourist activities and the promotion of activities that not only enable and enhance the sustainability of rural and natural regions from an anthropocentric perspective, but also focus on the welfare of the non-human animals involved in these activities. Undeniably, these aims are challenging given the diversity of the stakeholders' objectives and goals. However, it is possible to bridge the gap between stakeholders, as demonstrated in this field note.

\section{Disclosure statement}

No potential conflict of interest was reported by the authors. 


\section{Notes on contributors}

A. M. Antão-Geraldes earned her PhD in Biology and Ecology from Lisbon University, Portugal. Her research interests are mainly focused on the sustainable management, conservation and bioremediation of freshwater and terrestrial ecosystems. Currently, she is an Auxiliary Professor at the School of Agriculture at Polytechnic Institute of Bragança.

$V$. A. Sheppard, earned her PhD in the Environment from Simon Fraser University, Canada. Her research interests are focused on ethical behaviour, animal ethics, and sustainable development, particularly within the field of tourism. She is an Associate Professor at Universidade Europeia, in Lisbon, Portugal.

\section{ORCID}

A. M. Antão-Geraldes (D) http://orcid.org/0000-0003-4966-2227

V. A. Sheppard (i) http://orcid.org/0000-0003-0029-4339

\section{References}

Arrondo, A., Moleón, M., Cortés-Avizanda, A., Jiménez, J., Beja, P., Sánchez-Zapata, J. A., \& Donázar, J. A. (2018). Invisible barriers: Differential sanitary regulations constrain vulture movements across country borders. Biological Conservation, 219, 46-52.

Carvalho, A. M., \& Frazão-Moreira, A. (2011). Importance of local knowledge in plant resources management and conservation in two protected areas from Trás-os-Montes, Portugal. Journal of Ethnobiology and Ethnomedicine, 7, 36.

Fernandes, A. A. A. (2015). Património Cultural Mirandês. Um contributo para uma abordagem político-económica [Mirandese cultural heritage. A contribution to a political-economic approach] (Master's thesis). Retrieved from http://repositorio.ipvc.pt/bitstream/20.500.11960/ 1600/1/Alberto_Fernandes.pdf

Instituto Nacional de Estatística (INE). (2012). Censos 2011: resultados definitivos. Retrieved from http://censos.ine.pt/ngt_server/attachfileu.jsp?look_parentBoui=148313382\&att_display=n\&att_ download $=\mathrm{y}$

Kastenholz, E., Carneiro, M. J., Marques, C., Loureiro, S., Figueiredo, E., \& Pereiro, X. (2014). A experiência turística no espaço rural [The tourist experience in rural areas]. In E. Kastenholz, et al. (Eds.), Reinventar o turismo rural em Portugal : cocriação de experiências turísticas sustentáveis [Reinventing rural tourism in Portugal: Co-creation of sustainable tourism experiences] (pp. 43-50). UA Editora.

Monteiro, A. E. (2011). Variações locais no clima e taxas reprodutivas de cinco aves rupícolas [Local variations in climate and reproductive rates of five rupicolous birds] (Master's thesis). Retrieved from http://hdl.handle.net/10773/8470

Pigram, J. J. (1990). Sustainable tourism - policy considerations. Journal of Tourism Studies, 1(2), 2-9.

Quaresma, M., Martins, A. M. F., Rodrigues, J. B., Colaço, J., \& Payan-Carreira, R. (2014). Viability analyses of a donkey breed endangered of extinction: The case of the Asinina de Miranda (Equus asinus). Animal Production Science, 55(9), 1184-1191.

Rodrigues, S., Cadavez, V., \& Teixeira, A. (2006). Breed and maturity effects on Churra Galega Bragançana and Suffolk lamb carcass characteristics: Killing-out proportion and composition. Meat Science, 72(2), 288-293.

Sousa, F., Blanco-Penedo, I., Cantalapiedra, J., Sanchez, L., Iglesias, A., Colaço, A. J., \& PayanCarreira, R. (2018). Contribuição de fatores não-genéticos para o desempenho reprodutivo de vacas mirandesa. Archivos de Zootecnia, 67, 200-210.

Van Beest, F., Van Den Bremer, L., De Boer, W. F., Heitkönig, I. M. A., \& Monteiro, A. E. (2008). Population dynamics and spatial distribution of Griffon Vultures (Gyps fulvus) in Portugal. Bird Conservation International, 18(2), 102-117. 